\title{
Phenology of desert plants from an arid gravel plain in eastern United Arab Emirates
}

\author{
Sabitha SAKKIR ${ }^{1 *}$, Junid N SHAH ${ }^{1}$, Abdul J CHERUTH ${ }^{2}$, Maher KABSHAWI ${ }^{1}$ \\ ${ }^{1}$ Terrestrial and Marine Biodiversity Sector, Wildlife Assessment and Conservation, Environment Agency-Abu Dhabi, Abu Dhabi 45553 , \\ United Arab Emirates; \\ ${ }^{2}$ Department of Aridland Agriculture, College of Food and Agriculture, United Arab Emirates University, Al Ain 15551, United Arab \\ Emirates
}

\begin{abstract}
Phenological events for desert plants were recorded and rainfall and temperature data were gathered over a three-year time scale at a gravel plain in the eastern region of the United Arab Emirates. Variations of phenological periods were analyzed and correlations between phenological periods and climate factors were discussed. The study showed that the growth and flowering of therophytes were significantly correlated with air temperature. The timing and abundance of rainfall came to be another factor significantly correlated with the onset and duration of chamaephyte flowering as well as the duration of therophyte growth and flowering. The variation in rainfall did not affect the onset of flowering in phanerophytes. Peak growing seasons were from November to March and flowering from November to December (also February to March depending on the availability of rainfall). Flowering in phanerophytes and chamaephytes occurs 4-6 weeks and in therophytes 4-8 weeks after rain. The results showed that variations in growth and phenology between species were correlated with environmental factors, such as temperature and rainfall or, maybe, differences in life form and photosynthetic pathways, each being adapted for utilizing a particular phase of the seasonally and yearly variable rainfall. The sequence of flowering for the species under study was more or less constant despite the difference in the amount of rainfall. The fruiting patterns of most of the species were also found parallel to their flowering patterns. Our results emphasized the need to study multiple species at many sites for the understanding and forecast of regional changes in phenology.
\end{abstract}

Keywords: desert plants; phenology; temperature; rainfall; United Arab Emirates

Citation: Sabitha SAKKIR, Junid N SHAH, Abdul J CHERUTH, Maher KABSHAWI. 2015. Phenology of desert plants from an arid gravel plain in eastern United Arab Emirates. Journal of Arid Land, 7(1): 54-62. doi: 10.1007/s40333-014-0036-2

Plant phenology, the study of periodic events such as bud opening, flowering, pollination and seed set in the life history of a plant is influenced by its environment. In fact, it is not only a physiological phenomenon of a plant itself, but a comprehensive indicator to the habitat, climate and hydrology in a region (Chang et al., 2012). Plants are usually well adapted to the seasonality of their environment, and shifts in their seasonal phenology provide compelling evidence that ecosystems are being influenced by climate change (Cleland et al., 2007). Phenophases of numerous species across the world are significantly influenced by global cli- mate (Ghazanfar, 1997; Chmielewski and Rötzer, 2001; Menzel, 2002; Matsumoto et al., 2003; Badeck et al., 2004; Du et al., 2010).

In arid regions, the phenophases of desert plants are influenced mainly by precipitation pattern and temperature (Rossi et al., 1999). Other influencing factors include the availability of soil moisture, duration of day light and the position of the seeds on mother plants (Ghazanfar, 1997). The climate of the United Arab Emirates is characterized by high temperature and low rainfall pattern (Brown et al., 2004). Despite

\footnotetext{
"Corresponding author: Sabitha SAKKIR (E-mail: ssakkir@ead.ae) Received 2014-01-20; revised 2014-05-24; accepted 2014-06-02

(C) Xinjiang Institute of Ecology and Geography, Chinese Academy of Sciences, Science Press and Springer-Verlag Berlin Heidelberg 2015
} 
the hyper arid conditions, the mountainous areas on the eastern region of the United Arab Emirates exhibit a high degree of consistency in seasonal pattern with a similar consistency in the phenology pattern.

Within the context of global warming, the correlation of plant phenology with climate change is currently a hotspot in phenological research and is mainly concentrated on the response of phenology to global warming, dealing with issues like the early advancement in spring phenology or delayed autumn phenology or even lengthening of plants growing periods (Chmielewski and Thomas, 2001; Chang et al., 2012). Numerous reports of climate impacts (Khanduri et al., 2008; Elsey-Quirk et al., 2011; McEwan et al., 2011) have repeatedly emphasized the significance of phenology in highlighting the impacts of climate warming on the natural eco-systems.

Alteration of organisms' developmental timing (phenology) is one of the most obvious changes affected by global climate change (McEwan et al., 2011). Several studies were done in different parts of the world had shown the effects of climate gradients on plant phenology (Suzuki et al., 2003; Valdez-Hernández et al., 2010; McEwan et al., 2011; Kariveya et al., 2012; Morellato et al., 2013).

Surface temperature is continuously rising in global level during the last 30 years and is recognized that the increase is influencing phenology, physiology and distribution of plants (Abeli et al., 2012). Studies on plant phenological patterns and their relationship to climate are very limited in the Arabian Peninsula. Phenological patterns on the desert shrubs of Oman have been detailed by Ghazanfar (1997) and by Abd El-Ghani (1997) in Saudi Arabia. The studies on the changes in local climatic factors and their influences on plant phenology in the United Arab Emirates are scanty. The present study discussed the phenological patterns of 75 plant species from January 2010 to December 2012. The phenological patterns included vegetative growth, flowering, fruiting and leaf fall. The aim of the study is to explore the relationships between the phenological patterns of desert plants and air temperature and the amount of rainfall.

\section{Materials and methods}

\subsection{Study area}

This study was done in a gravel plain in the eastern region of the United Arab Emirates $\left(24^{\circ} 01^{\prime}-24^{\circ} 10^{\prime} \mathrm{N}\right.$, $5^{\circ} 42^{\prime}-55^{\circ} 50^{\prime} \mathrm{E}$; Fig. 1), with an average elevation of $1,240 \mathrm{~m}$. The area is dissected by wadis, gullies and runnels with coarse gravelly and rocky substrate, and shallow drainage channels with sandy substrate. The natural vegetation of the area is dominated by Acacia tortilis and Euphorbia larica (Brown and Sakkir, 2004). The climate belongs to bi-seasonal Mediterranean type characterized by high temperature and low rainfall (Brown and Sakkir, 2004). The summer months are from June to September, winter from December to March, autumn from October to November and spring from April to May (Bottomley, 1996). The mean monthly temperature is $28^{\circ} \mathrm{C}$ and monthly average rainfall is $2.17 \mathrm{~mm}$ in the study area.

\subsection{Methods}

Phenological observations were monitored weekly during the spring and early summer from 2010 to 2012, when the plants were most active, and every four weeks during the other seasons of the year. The meteorological data were derived from the National Centre for Meteorology and Seismology, Abu Dhabi, United Arab Emirates. The observations covered four phenophases namely growth, flowering, fruiting and defoliation. The first three events can be termed as spring phenology, and the last as autumn phenology. A starting date is assigned to a phase when two or more individuals of the species were found to be in that phase (Kemp, 1983). Growth refers to the process of buds starting to develop on the plant in perennials and the formation of leaves in annuals, flowering period is the process of plant blooming; fruiting period is the process of plants bearing fruits, and defoliation period is the process of leaf falling in perennials and death in annual species. The correlations among air temperature, rainfall and growth and flowering were expressed with 


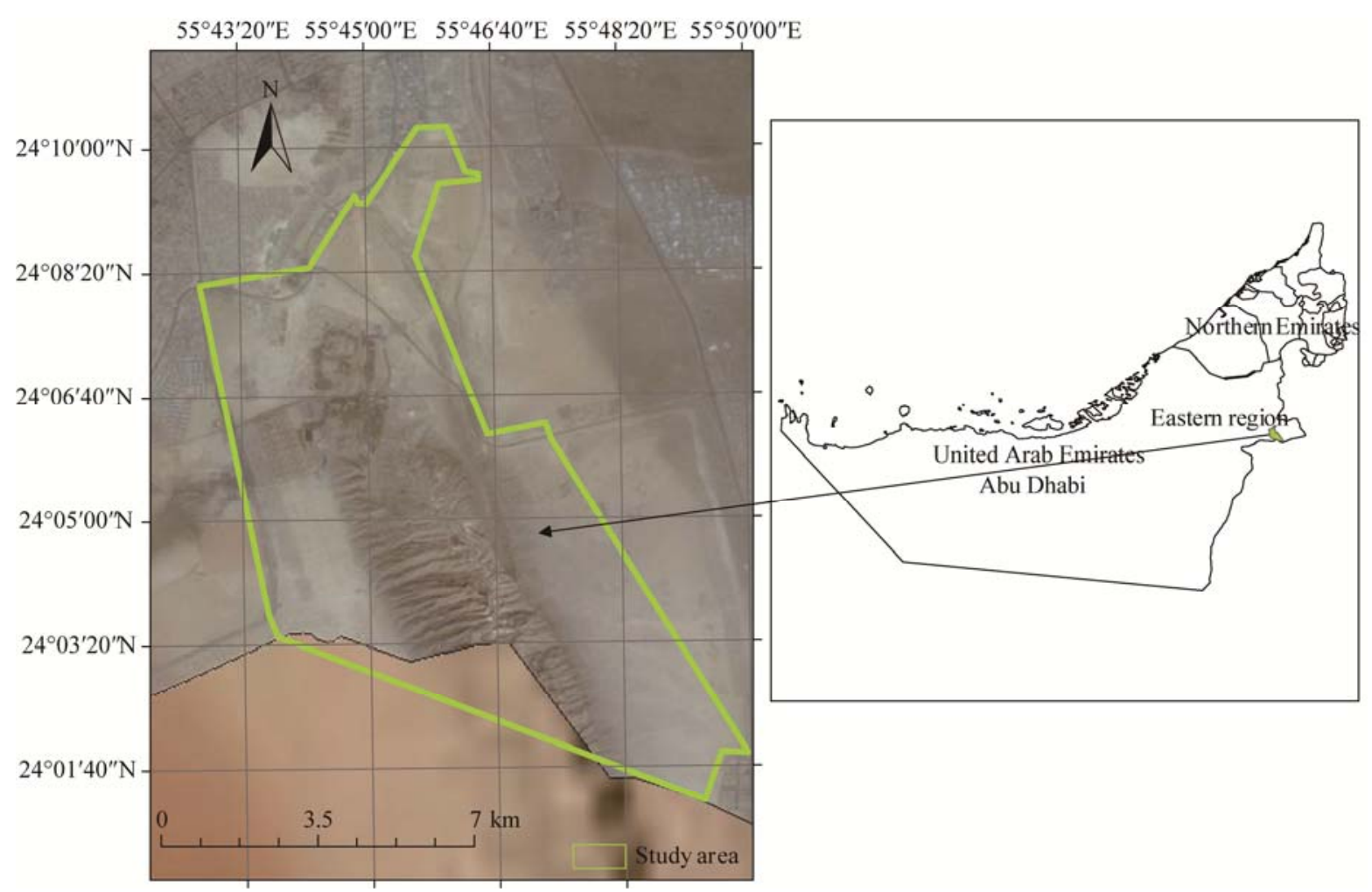

Fig. 1 Map of the study area (Al Ain region of Abu Dhabi Emirate)

Pearson correlation coefficient and relevant significances were tested. Plant specimens were named according to Jongbloed (2003) and life forms were recorded according to Raunkier (1934).

\section{Results}

A total of 75 species (50 perennials and 25 annuals) were collected during this study. Of these, $91 \%$ flowered in $2010,37 \%$ in 2011 and $60 \%$ in 2012 . These changes were mainly due to changes in the phenology of the therophytes. Species in which phenological patterns were observed and their life form categories were given in Figs. 2 and 3. During 2010 and 2012, the climatic records (Table 1) indicated that rainfall was most abundant in late summer or early winter (November-March).

\subsection{Growth}

Phenological patterns showed diversity between the species (Fig. 2). During almost all periods of the year, at least a few species were in some phase of growth or reproduction in perennials. Peak growing seasons were from November to March and flowering from
Table 1 Monthly mean temperature and rainfall $(n=3)$

\begin{tabular}{cccccc}
\hline \multirow{2}{*}{ Month } & \multicolumn{2}{c}{ Mean temperature } & & \multicolumn{2}{c}{ Rainfall } \\
\cline { 2 - 3 } \cline { 5 - 6 } & $\begin{array}{c}\text { Monthly } \\
\left({ }^{\circ} \mathrm{C}\right)\end{array}$ & $\begin{array}{c}\text { Coefficient of } \\
\text { variation }(\%)\end{array}$ & $\begin{array}{c}\text { Monthly } \\
(\mathrm{mm})\end{array}$ & $\begin{array}{c}\text { Coefficient of } \\
\text { variation }(\%)\end{array}$ \\
\hline January & 17.82 & 0.04 & & 3.43 & 1.31 \\
February & 19.43 & 0.05 & & 4.77 & 1.40 \\
March & 23.11 & 0.03 & & 4.63 & 1.34 \\
April & 28.27 & 0.01 & & 0.37 & 0.56 \\
May & 33.10 & 0.02 & & 0.07 & 1.41 \\
June & 35.07 & 0.01 & & 0.00 & 0.00 \\
July & 37.23 & 0.01 & & 0.00 & 0.00 \\
August & 36.20 & 0.04 & & 1.67 & 0.71 \\
September & 33.72 & 0.01 & & 1.60 & 1.33 \\
October & 29.72 & 0.02 & & 0.33 & 0.28 \\
November & 23.49 & 0.01 & & 8.03 & 0.71 \\
December & 18.60 & 0.08 & 1.23 & 0.68 \\
\hline
\end{tabular}

November to December and February to March depending on the availability of rainfall. In early spring (November), winter months (December to March) were characterized by extensive growth and reproductive activity of many annual and perennial species. In chamaephytes, growing periods were not correlated 
with the temperature $(r=0.633, P<0.01)$, whereas in therophytes growing periods were significantly correlated with the temperature $(r=0.021, P<0.01)$.

In addition to seasonal changes, there were variations in between-year phenology; most of which can be correlated with changes in moisture. Enough amounts of rainfall in late summer and early spring of 2010 provided substantial soil moisture for the growth of annual species. Growth of therophytes was restricted to the first quarter of each year. The rain that fell in November to March had a major influence on the growth of chamaephytes and therophytes (Figs. 2 and 3). In phanerophytes, the growth was recorded in all the three years, and occurred almost at the same time during the three years. Growth in chamaephytes was not correlated with the rainfall $(r=0.308, P<0.05)$ while it was correlated with growth in therophytes $(r=0.015, P<0.05)$

\subsection{Flowering}

Flowering in phanerophytes and chamaephytes varied from 4 to 6 weeks after rain, and for therophytes from 4 to 8 weeks. Flowering in the majority of chamaephytes and therophytes were recorded during December to March (Figs. 2 and 3). Of the chamaephytes, almost all species flowered in 2010, and then 51\% flowered in 2011 and 75\% flowered in 2012. Twelve

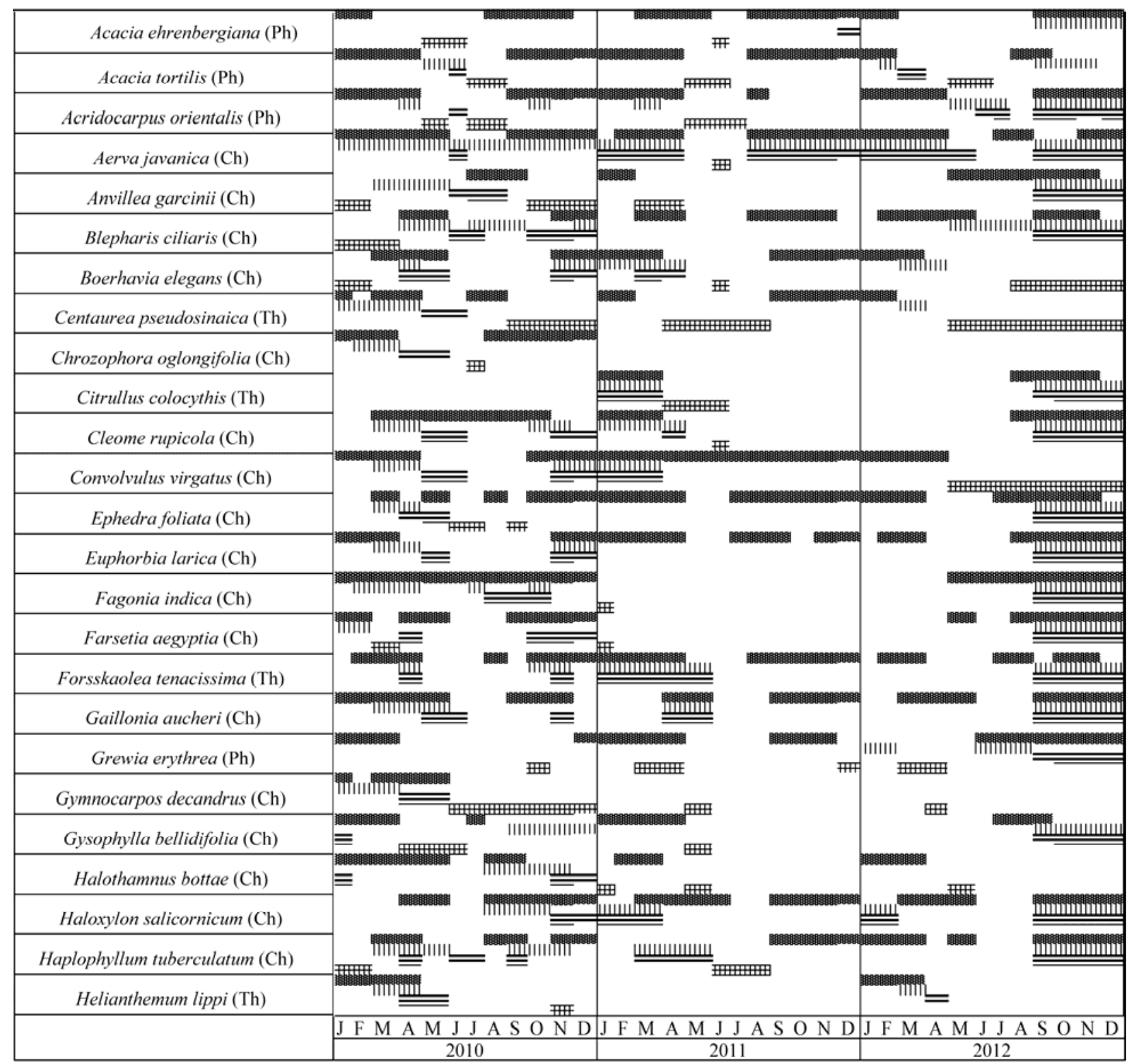




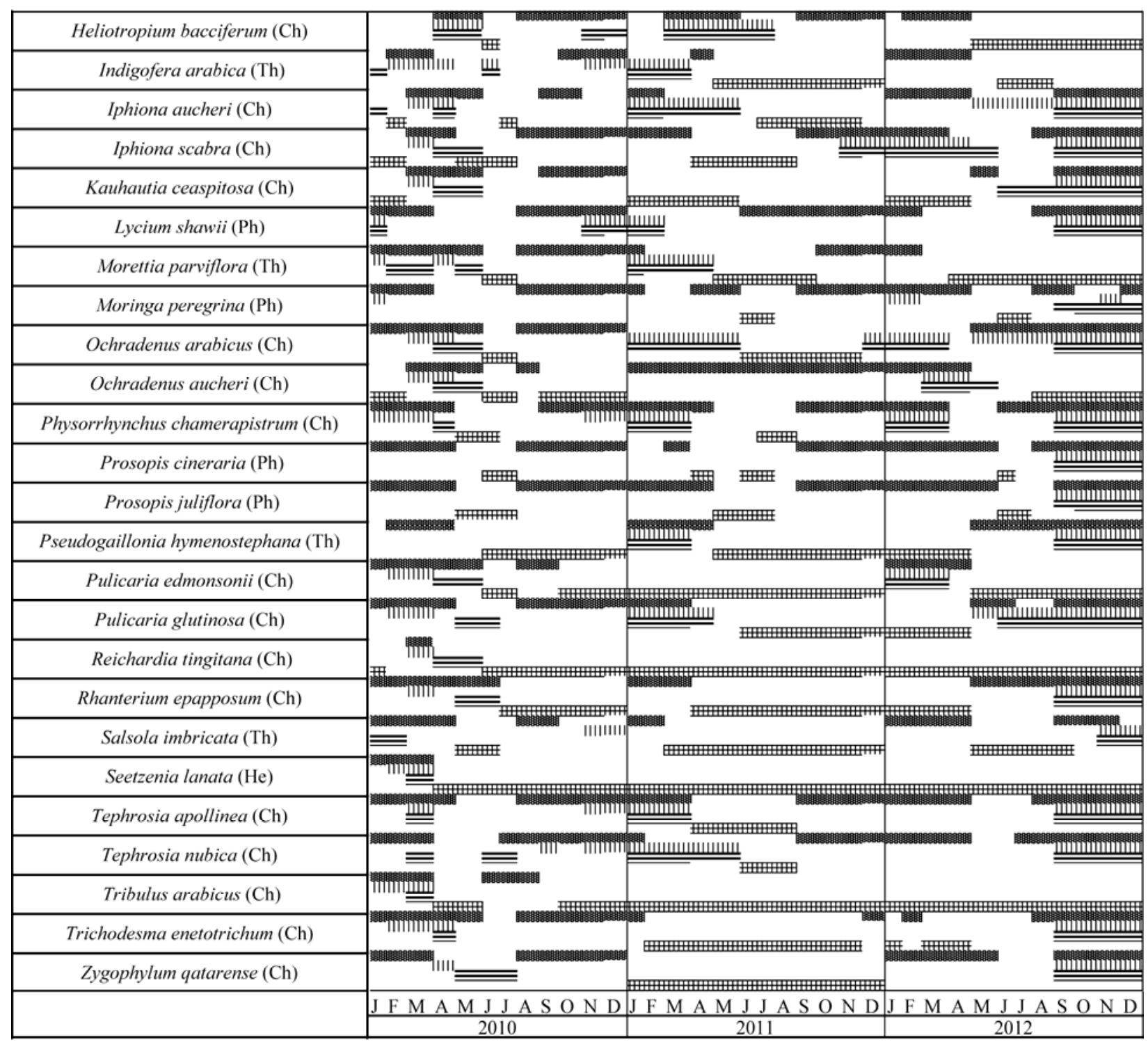

Fig. 2 Phenological events of 50 perennial species from January 2010 to December 2012. Four bars for each species represent four phenophases, $=$ mrowth;

species flowered in all the three years. Aerva javanica, Blepharis ciliaris, Halopeplis perfoliata, Physorrhynchus chamaerapistrum and Tephrosia apollinea had comparatively prolonged flowering periods and flowered in all the three years. In Seetzenia lanata growth and flowering were restricted to February to March 2010 with the onset of rainfall. The phanerophytes showed fluctuations in the flowering periods, with Acacia tortilis, Acridocarpus orientalis, Lycium shawii and Moringa peregrina had prolonged flowering periods. When the onset of flowering was compared between the three years, the majority of the phaner- ophyes flowered in 2012. Of the 25 annuals, almost all the species flowered in 2010, and then $28 \%$ in 2011 and $36 \%$ in 2012. Flowering was restricted to the first quarter (between January to early May) of each year, with the majority of the species flowered in 2010, with the comparatively heavy rain in that year. Most species did not flower in 2011, and the species which did flower occurred at the same time as others, except Crotalaria persica and Reseda aucheri which flowered earlier. Flowering of Hippocrepis areolata and Schweinfurthia papilionacea was observed in the last quarter of 2012. Flowering of Cleome brachycarpa 


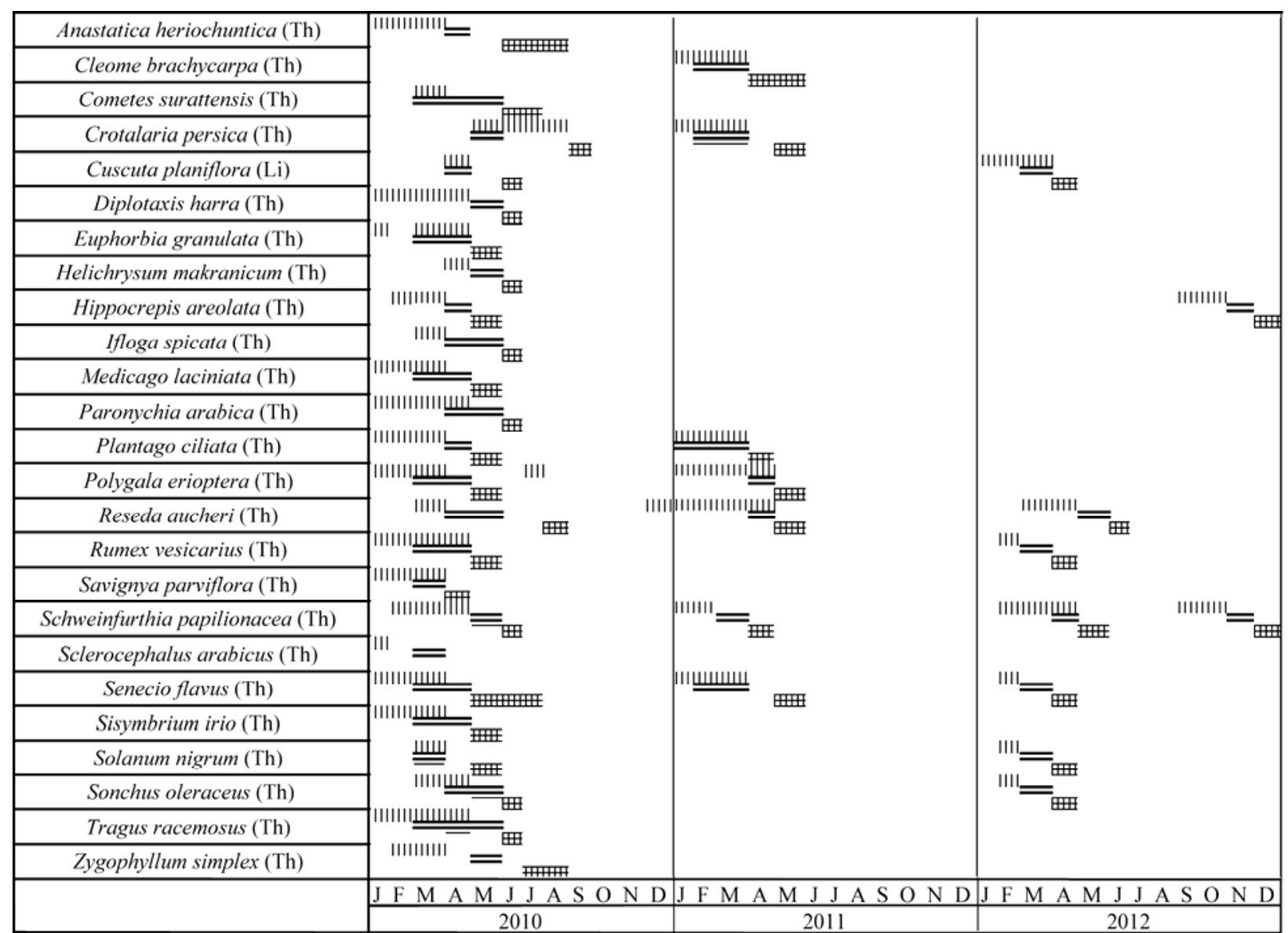

Fig. 3 Phenological events of 25 annual species from January 2010 to December 2012. Three bars for each species represent three

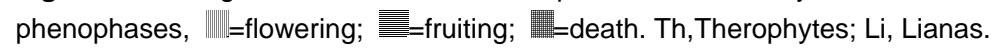

was restricted only in the first quarter of 2011. When the onset of flowering was compared between the three years; it was earlier in 2011 for some species and delayed by $2-3$ weeks in 2012 , but occurred at the same time for others (Figs. 2 and 3). In chamaephytes, flowering periods was correlated with the temperature $(r=0.034, P<0.05)$, as well as for therophytes $(r=0.006$, $P<0.05)$.

Flowering in chamaephytes and therophytes was correlated with the rainfall $(r=0.002, r=0.003, P<0.05)$. Floweing in phanerophytes did not show any correlation with the rainfall $(r=0.411, P<0.05)$.

\subsection{Fruiting}

Most of the perennial and annual species showed fruiting after flowering. Most of the perennials fruited in April to June in 2010, January to May in 2011, and January to May and September to December in 2012, following the patterns of flowering in these years
(Figs. 2 and 3). In most of species, flowering and fruiting were observed at the same time. Flowering and fruiting in annuals were restricted to the first quarter of each year in almost all species, except Hippocrepis areolata and Schweinfurthia papilionacea which exhibited flowering and fruiting in the last quarter of 2012.

\subsection{Abscission}

In this study, all perennial species shed their leaves in the summer months. For all therophytes, death followed fruiting which occurred from May to July in all the three years (Fig. 3). Many therophytes which occurred in 2010 reoccurred only in 2012. In case of chamaephytes, most of the species were drought deciduous and shed their leaves in the late spring and summer months (May-July). Species like Reichardia tingitana, Tribulus arabicus and Seetzenia lanata were found only in the first quarter of 2011. There was 
slight variation in the abscission pattern between the years which was either delayed or earlier by 3-4 weeks. Phanerophytes were partially deciduous and shed their leaves in June to September in all the three years.

\section{Discussion and conclusion}

Phenological events are triggered mainly by rainfall and suitable temperature, although photoperiod is probably important for some species. The environmental regime that triggers a particular phenological stage varies among species: annual plants will not germinate and develop unless moisture and temperature conditions are suitable. The main phenological patterns in the annual and perennial species can be summarized as follows: (1) Onset of growth and flowering was dependent on the rainfall and was found earlier and prolonged flowering period with early rainfall; (2) There was a significant correlation between the commencement of flowering in therophytes with mean monthly temperature; (3) There was a significant correlation between the commencement of growth and flowering in therophytes from 5 to 8 weeks after rain; (4) For the therophytes, there was significant correlation between the commencement of growth and flowering with mean monthly temperature and rainfall; (5) In chamaephytes the correlation of growth and flowering is not significant with either temperature or rainfall; (6) In chamaephytes and phanerophytes, flowering and fruiting were normally separated, while in therophytes the two phenophases were usually synchronized; (7) Related species appeared to stagger their flowering but the flowering of annuals was primarily a response to rain; (8) The sequence of flowering between species was generally constant despite fluctuations in the timing and amount of rainfall.

The results of this study showed that temperature and flowering in therophytes were significantly correlated. Low moisture or low temperatures may result in a delayed start of the growth season. Fitter and Fitter (2002) demonstrated that in a data set, about $83 \%$ of the 385 species exhibit a significant relationship with mean monthly air temperature. Our data supports this result. However, studies by Aronson et al. (1992) showed that rapid increase in temperature during the spring time, as well as decreasing rainfall and increasing evaporation resulted in shorter growing seasons which could not be validated in our patterns. Given the fact that flowering dates from one year to the next fluctuate wildly, a long-term monitoring (at least a decade), especially by many observers, may be needed to capture sensitivity like earlier flowering date generally related to global warming.

The deserts in the United Arab Emirates are generally characterized by winter rains and slight summer showers. The major annuals here are seasonal winter ones, except that Schweinfurthia papilionacea was found to be flowering twice in spring and early winter in 2012. The fluctuation in the amount of rainfall has an effect on the overall growth and flowering of the annuals. In deserts, evaporation rates are higher than precipitation and the amount of annual rainfall is highly variable from one year to the next (Went, 1949; Evenari et al., 1982; Gutterman, 2012). Many annuals which were found in the first year are not present in the second and third years. Studies by Aronson et al. (1992) support the fact that in some years no annuals germinate and the onset of the growing season, in those years, was dependent on the unpredictable timing of the first good rain. Since auto-correlation in rainfall is very low in the deserts (Evenari et al., 1982), water availability following germination is highly unpredictable, leading to very high probability of stress and possibly death during the growth season for annual plants. Studies by Gutterman (1999) showed one-season winter annual plant species flowering in March and April in their natural habitats. Similar observations were found during the present day when the temperature and soil moisture were suitable for the growth of therophytes.

Like deserts in other parts of the world (e.g. Sonoran, Mojave and Chihuahuan deserts), where most of the dominant species depend heavily on the seasonal availability of the soil moisture to bring flowers and fruits from initial to final stages (Beatley, 1974; Simpson, 1977; Solbrig and Yang, 1977; Kemp, 1983; Bowers and Dimmit, 1994), UAE's desert species also show strong dependency. In the study area, a significant rain was the trigger that initiates flowering. For these reasons flowering time for most species must 
coincide with the seasons of the greatest soil moisture to thrive. Sometimes, flowering times of some desert plants may be constrained by the need to produce seeds in time of germination in the summer rainy season as suggested by Solbrig and Yang (1977). Likewise, Crimmins et al. (2013) indicated that flowering metrics, especially constancy and duration, showed similar patterns in spring and summer which varied across elevation and moisture gradients.

Synchronization and constancy in the sequence of flowering in desert plants had been discussed by other authors (Struck, 1994; Ghazanfar, 1997). Such constancy was exhibited by some groups of species in our data as well. This probably helps in maximizing the use of available moisture and minimizing drying of flowers and immature fruits during the subsequent dry seasons (something to study further). Flowering times have been determined by the seed germination needs and the pollinator availability and competition for pollinators by many authors (Palladini and Maron, 2012; Fründ et al., 2013). In fact, rather than avoiding competition for pollination, the two phanerophytes, Acacia tortlis and Lycium shawii were found flowering at the same time.

Phenological requirements of species differ. As shown by Beatley (1974) and Ludwig and Whitford (1981), the phenological stages; which have been recorded in our study for many species; generally correlated with habitat moisture. The long-term phenological record at one site presents an opportunity to examine changes in the date of occurrence of various phenophases over a period of climate change. We speculate that species without phenological adaptability may experience greater stress or extinction during extended climate change. But long term (perhaps spanning several decades) data are needed to validate the macro impacts like global warming.

As reported by Kemp (1983), differences in life form and photosynthetic pathways are other ways in which plants seem to form groups adapted for growth at different seasons. Crimmins et al. (2014) reported within-season flowering occurrence in plants in both distinct spring and summer seasons. Due to the shortage of long-term data, we are unable to measure shifting days of the phenophases. Anomaly of climate pat- tern and extreme weather event were not taken into consideration during the study. Our results emphasize the need to study multiple species at many sites for the understanding and forecast regional changes in phenology.

\section{Acknowledgements}

We would like to thank Dr. Annette MENZEL, Dr. Faisal ARIF and Dr. Abd El-GHANI for their invaluable suggestions to the manuscript. We also thank Dr. Abdul Nasser SHAMSI and Dr. Shaikha Salem Al DHAHERI, Terrestrial and Marine Biodiversity Sector, Environment Agency-Abu Dhabi for their support and encouragement.

\section{References}

Abd El-Ghani M M. 1997. Phenology of ten common plant species in Western Saudi Arabia. Journal of Arid Environments, 35: 673-683.

Abeli T, Rossi G, Gentili R, et al. 2012. Response of alpine plant flower production to temperature and snow cover fluctuation at the species range boundary. Plant Ecology, 213(1): 1-13.

Aronson J, Kigel J, Shmida A, et al. 1992. Adaptive phenology of desert and Mediterranean populations of annual plants grown with and without water stress. Oecologia, 89: 17-26.

Badeck F W, Bondeau A, Böttcher K, et al. 2004. Responses of spring phenology to climate change. New Phytologist, 162: 295-309.

Beatlye J C. 1974. Phenological events and their environmental triggers in Mojave Desert ecosystems. Ecology, 55: 856-863.

Both C, Bouwhuis S, Lessells C M, et al. 2006. Climate change and population declines in a long-distance migratory bird. Nature, 441: 81-83.

Bottomley N. 1996. Recent climate of Abu Dhabi. In: Osborne P E. Desert Ecology of Abu Dhabi. Abu Dhabi: National Avian Research Centre, 36-49.

Brown G, Sakkir S. 2004. Flora and vegetation of Jebel Hafit. In: Jebel H A Natural History. Abu Dhabi: Emirates Natural History Group.

Chang Z F, Zhu S J, Han F G, et al. 2012. Differences in response of desert plants of different ecotypes to climate warming: a case study in Minqin, Northwest China. Journal of Arid Land, 4(2): 140-150.

Chmielewski F M, Rötzer T. 2001. Response of tree phenology to climate change across Europe. Agricultre and Forest Meteorology, 108: 101-112.

Cleland E E, ChuineI M A, Mooney H A, et al. 2007. Shifting seasonal phenology in response to global change. Trends in Ecology and Evolution, 22: 357-365.

Crimmins T M, Crimmins M A, Bertelsen C D. 2013. Spring and summer patterns in flowering onset, duration, and constancy across a water-limited gradient. American Journal of Botany, 100(6): 1137-1147.

Crimmins T M, Bertelsen C D, Crimmins M A. 2014. Within-season flowering interruptions are common in the water-limited Sky Islands. International Journal of Biometeorology, 58: 419-426. 
Du J H, Yan P, Dong Y X. 2010. Phenological responses of Nitraria tangutorum to climate change in Minqin County, Gansu Province, North West China. International Journal of Biometeorology, 54: 583-593.

Elsey-Quirk T, Seliskar D M, Gallagher J L. 2011. Differential population response of allocation, phenology, and tissue chemistry in Spartina alterniflora. Plant Ecology, 212(11): 1873-1885.

Evenari M, Shanan L, Tadmor N. 1982. The Negev: Challenge of a Desert $\left(2^{\text {nd }} e d\right)$. Cambridge: Havard University.

Fründ J, Dormann C F, Holzschuh A, et al. 2013. Bee diversity effects on pollination depend on functional complementarity and niche shifts. Ecology, 94: 2042-2054.

Ghazanfar S A. 1997. The phenology of desert plants: a 3-year study in a gravel desert wadi in northern Oman. Journal of Arid Environments, 35: 407-417.

Inouye D W, Barr B, Armitage K B, et al. 2000. Climate change is affecting altitudinal migrants and hibernating species. Proceedings of National Academy of Science, USA, 97: 1630-1633.

Jongbloed M. 2003. The Comprehensive Guide to the Wild Flowers of the United Arab Emirates. Abu Dhabi: Environmental Research and Wildlife Development Agency (ERWDA).

Ludwig J A, Whitford W G. 1981. Short-term water and energy flow in arid ecosystems. In: Goodall D W, Perry R A. Arid-land Ecosystems: Structure, Functioning and Management. Cambridge: Cambridge University Press, 271-299.

Kariyeva J, Leeuwen, J D, Woodhouse C A. 2012. Impacts of climate gradients on the vegetation phenology of major land use types in Central Asia (1981-2008). Frontiers of Earth Science, 6: 206-225.

Kemp P R. 1983. Phenological patterns of Chihuahuan desert plants in relation to the timing of water availability. Journal of Ecology, 71: 427-436.

Khanduri V P, Charma C M, Singh S P. 2008. The effects of climate change on plant phenology. Environmentalist, 28: 143-147.

Matsumoto K, Ohta T, Irasawa M, et al. 2003. Climate change and extension of the Gingko biloba L. growing season in Japan. Global Change Biology, 9: 1634-1642.

McEwan R W, Brecha R J, Geiger D R, et al. 2011. Flowering phenology change and climate warming in southwestern Ohio. Plant Ecology, 212(1): 55-61.

McLaren K P, McDonald M A. 2005. Seasonal patterns of flowering and fruiting in a dry tropical forest in Jamaica. Biotropica, 37(4): 584-590.
Menzel A. 2002. Phenology: its importance to the global change community. Climate Change, 54: 379-385.

Morellato P C, Camargo M G, Gressler E. 2013. A review of plant phenology in South and Central America. In: Schwartz M D. Phenology: An Integrative Environmental Science. Netherlands: Springer, 91-113.

Palladini J D, Maron J L. 2012. Indirect competition for pollinators is weak compared to direct resource competition: pollination and performance in the face of an invader. Oecologia, 172: 1061-1069.

Post E, Forchhammer M C. 2008. Climate change reduces reproductive success of an Arctic herbivore through trophic mismatch. Philosophical Transactions of the Royal Society B: Biological Sciences, 363: $2367-2373$.

Raunkiaer C. 1934. The Life Forms of Plants and Statistical Plant Geography. Oxford: Oxford University Press.

Rossi B E, Debandi G O, Peralta I E, et al. 1999. Comparitive phenology and floral patterns in Larrea species (Zygophyllaceae) in the Monte desert (Mendoza, Argentina). Journal of Arid Environments, 43: 213-226.

Stenseth N C, Mysterud A. 2002. Climate, changing phenology, and other life history and traits: nonlinearity and match-mismatch to the environment. Proceedings of National Academy of Science, USA, 99: 13379-13381.

Struck M. 1994. Flowering phenology in the arid water rainfall region of Southern Africa. Bothalia, 24(1): 77-79.

Suzuki R, Nomaki T, Yasunari T. 2003. West-east contrast of phenology and climate in northern Asia revealed using a remotely sensed vegetation index. International Journal of Biometeorology, 47(3): 126-138.

Valdez-Hernández M, Andrade J L, Jackson P C, et al. 2010. Phenology of five tree species of a tropical dry forest in Yucatan, Mexico: effects of environmental and physiological factors. Plant and Soil, 329: $155-171$

Visser M E, Both C. 2005. Shifts in phenology due to global climate change: the need for a yardstick. Proceedings of the Royal Society B: Biological Sciences, 272: 2561-2569.

Walter H. 1973. Vegetation of the Earth. London: Springer-Verlag.

Winder M, Cloern J E. 2010. The annual cycles of phytoplankton biomass. Philosophical Transactions of the Royal Society B: Biological Sciences, 365: 3215-3226. 